\title{
ACTIVITY OF A HIGHER SCHOOL TEACHER ON FORMING SOFT SKILLS FOR STUDENTS OF HUMANITARIAN AND NATURAL SPECIALTIES: FUNCTIONS AND REQUIREMENTS
}

\author{
Oksana Zhukova \\ $\mathrm{PhD}$, Associate Professor, V. N. Karazin Kharkiv National University, Ukraine \\ e-mail: edu.pedagogika@gmail.com,orcid.org/0000-0001-9724-9598
}

\section{Summary}

Based on studied materials the author concludes that modern national pedagogical science is taking the first step towards building conceptual foundations for the formation of soft skills by primary school children as part of the concept of "New Ukrainian School". The issue of soft skills formation in higher education institutions remains highly important.

The purpose of the article was to describe functions that the teacher performs in the process of forming soft skills.

In the course of study within the framework of each function, the author determined the following requirements to actions of teachers to form soft skills by students: *the educational: the organization of effective communication in various types of extracurricular work; *the didactic: the use of modern pedagogical technologies; *the research: defining principles, approaches and conditions that have a significant impact on the formation of soft skills; *the projective: modeling various types of activities for mastering soft skills; *the organizational and managerial: describing in detail ways of solving the assigned tasks by using specific pedagogical techniques and methods; *the predictive: determining the main areas of activity based on conditions, forms, components, and levels of forecasting; *the methodological: mastering the principles and methodological techniques of organizing and conducting trainings, round tables, workshops, speaking in classes during extracurricular work; *the facilitative: the organization of multilevel interaction in the "teacher-to-student" and "student-to-student" modes in accordance with the "attributive circle" of facilitation process.

Keywords: pedagogical technologies, education, didactics, research, projecting, organization and management, methodology, facilitation.

DOI https://doi.org/10.23856/3931

\section{Introduction}

Higher education is one of the most important elements of human development. Its gives the individual a certain level of qualification, the possibility of employment and demand in society. It plays a leading role in the functioning of social institutions. Correspondence of the content of higher education to the needs of modern society in the process of professional training is the basis for the development of human beings as a person and as a specialist. One of the urgent requirements of modern society is the formation of soft skills by future employees - skill spreading across different professions and subject, mastering of which allows you to establish relationships with others, to solve complex problems, to build a career, to learn throughout the life cycle, to train others, and to feel self-confident and self-sufficient.

The need for the formation of soft skills in the XXI century is noticed in the works of foreign scientists (Pachauri, Yadav, 2014; Snape, 2017), in the research of global organizations and institutions (Human Development Report, 2019; Skill Shift Automation, 2018; Shvab, 2017). 
They indicate the importance of the practical use of these skills in the process of organizing a person's life, migration processes, overcoming poverty and establishing infrastructure.

In modern national pedagogical science, the first steps have been taken towards the construction of conceptual foundations for the formation of soft skills in children of primary school age, which include goal-setting, communication in a multicultural space based on knowledge of the native language and foreign languages, critical thinking, teamwork, etc. The Concept of "New Ukrainian School" is focused heavily on these issues (Bibik, 2017).

Unfortunately, the requirements for the activity of a higher school teacher in the formation of soft skills in the system of professional training are still beyond the area of attention of researchers: the modern source base is represented by studies dealing with the issues of general foundations of teacher's activity, his functional duties, and the competencies that he forms and improves in future specialists in the process of his own activity.

The purpose of the article is to describe functions that the teacher carries out, as well as the requirements that go along with his activity in the process of forming soft skills in higher education students of humanitarian and natural specialties when studying the humanitarian disciplines.

To achieve this goal we used methods of analysis of psychological and pedagogical sources as well as methods of synthesis of information necessary to describe specific functions of a teacher in the process of forming students' soft skills.

\section{The educational function}

In the context of changes caused by Industry 4.0, the formation of soft skills among students acquires a particular importance (Shvab, 2017). When students study humanitarian disciplines, this process requires that teachers follow certain requirements.

The requirements, in turn, are determined by the functions that pedagogues perform in the process of carrying out their activity. The actions of the teacher affect the quality of educational process and are determined by its goals and objectives; the model of training and organization of this process in a particular institution; availability of resources; the age and individual characteristics of students, etc. (Zagvyazinskij, Atahanov, 2010: 59-64; Bordovskaya, Rean, 2011: 83). In our research we focus on teachers' carrying out educational, didactic, research, projecting, organizational and managerial, prognostic, methodological, facilitative functions, as well as those requirements that are imposed on the teacher in the process of forming soft skills in students in the context of these functions.

The implementation of the educational function by the teacher is associated with the organization of his activities in the classroom (the educational influence of training) and extracurricular work. The organization of extracurricular activities of students is one of the most important issues facing higher education. Its multidimensional character is emphasized in the works of modern scientists (Bobro, 2017; Breslavska, 2013; Dubaseniuk, 2005; Halatsyn, 2014; Humennykova, 2004; Koval, 2009; Ovcharenko, 2008; Petrychenko, 2010; Skrypnyk, 2012). In the studies of these authors, extracurricular work acts as a factor and a condition that has a definite impact on the processes of adaptation of students to the educational process, improving quality of professional training and the formation of an active professional position, enhancing the educational process, formation of socially significant personality traits in students, and development of their creativity.

The analysis of the works of these authors allows us to state that the organization of extracurricular activities in higher education promotes: entry into the environment of cultural, intellectual, creative communication; creating conditions for the assimilation of material culture 
and spiritual values by students; further formation of value orientations; the formation of social position and life ideals; development of social needs and interests; inclusion in the system of social relations; identification and manifestation of the individual's capabilities.

As part of the formation of Soft Skills in students, the teachers' conduct of educational functions will consist in creating the educational environment and determining a set of activities that should be carried out in the classroom and as extracurricular work. This process will be successful if the teacher determines goals, functions, tasks, forms and types of extracurricular activities; their essence, structure, content, the specifics of the formation of "soft skills" among students of humanitarian and natural specialties. An important role in this process is played by the organization of interaction in the "teacher-to-student" and "student-to-student" mode in various types of extracurricular work.

Among the requirements that are imposed on the activities of a teacher in the process of forming students' soft skills, we emphasize the following:

- determining the goals of extracurricular work: the formation of students' attitude to the environment and to themselves through their understanding the nature of this interaction, their own capabilities and individual characteristics; accumulation of personal experience thanks to which it is possible to resolve issues and overcome obstacles standing in the way of personal and professional growth of students; increasing the level of social competence the formation of which allows one to give an adequate assessment of the processes of interaction, to build conflict-free relations with others, prevent manifestations of misunderstanding; further development of abilities for positive self-change through self-education; improving the qualities that characterize students as a creative individual;

- directing activities to in order to increase the motivation of students for self-realization, mobilization of their efforts to complete the task;

- building a strategy of educational work on the following principles: respect for the student's personality; performing collective affairs; differentiated and individual approaches; reliance on positive individual qualities and actions of students; consistency of actions of all participants;

- the teacher conducting a wide range of role positions: as adviser, a mentor, a facilitator, a curator, a coach;

- using the following methods: setting a positive example; exercises aimed at strengthening the determination of students, the formation of positive habits, the accumulation of experience, rational behavior, independent making the right decisions; beliefs which allow you to translate conclusions into practical actions; encouragement thanks to the teacher stimulates positive emotions and creates a psychologically relaxed atmosphere;

- receiving and analyzing feedback on the implementation by the teacher of individually-specific and functional-role types of influence.

\section{The didactic function}

The didactic function is aimed at disclosing the teacher's abilities to consistently and logically present the material necessary for the development of students and to take into account the level of their training for its perception and performance of independent work (Zagvyazinskij, Atahanov, 2010: 182).

This function involves the choice of forms, principles and methodson the basis of which the process of communication with students will be built in a manner opening the room for receiving feedback, depending on a particular education model (Bordovskaya, Rean, 2011: 69-71): the 
developing education, the purpose of which is to develop theoretical thinking of students; the traditional one which involves the formation of students' knowledge, skills and abilities as a basis for their further independent assimilation of information from various sources; the rationalistic according to which the individual assimilates cultural values and acquires the necessary knowledge for better adaptation in society; the phenomenological in which education is viewed from the standpoint of human-centrism, i.e., by means of taking into account his individual and psychological characteristics; non-institutional one the main postulates of which is the development of personality through the organization of educational activities outside of government institutions.

Based on the analysis of researchers' work (Ibragimov, Ibragimova, Andrianova, 2011; Slastenin, Isaev, Mishenko, Shiyanov, 2000) we identified the following requirements to the teacher's didactic function during the formation of soft skills in students:

- determination of the model of education and forms of activity with students, depending on the segment of the educational system (formal or informal);

- a clear understanding of the principles of organizing one's own activities (a combination of pedagogical management with the development of initiative and independence of students; consciousness and activity of students; respect for the student's personality combined with reasonable demands to students; reliance on the positive in a person, on the strengths of his personality; taking into account students' individual characteristics in the process of organizing their activities; coordination of actions of the teacher and students, a combination of direct and parallel pedagogical actions);

- the teacher's possession of a wide variety of teaching techniques (techniques for activating memory, imagination, perception, individual thinking operations; techniques for creating problem-and-search situations in the process of forming these skills; techniques for activating the experiences and feelings of students; techniques for self-learning, control and self-control; techniques for managing personal and collective relationships);

- the use of various types of teaching methods (traditional, active, interactive);

- the use of modern pedagogical technologies (problem learning, interactive learning, play activities, case learning, the development of critical thinking, creating situations of success). Their impact will be enhanced through the use of pedagogical guidance technology, which includes support and facilitative assistance.

\section{Research function}

The activity of the teacher in the implementation of his research function is based on the principles of scientific systemic search, deep and versatile study of the phenomenon under study in dynamics, objectivity and sequence of search actions (Dubaseniuk, 2013: 20-21). It provides:

- the application of research knowledge in the field of practical activities;

- building activities based on the use of methods of scientific and pedagogical research that are effective for specific situations;

- striving to develop skills in research activity;

- taking into account the difficulties faced by students during research activities;

- selection of effective ways to enhance research work;

- organization of students' independent work based on the fulfillment of individual and collective tasks.

Among the conditions for the success of research work, scientists emphasize correspondence of research tasks to the modern requirements of society; research support through methodological, organizational, and resource support; systemic nature of activity (Dubaseniuk, 2013; Honcharenko, 2012). 
The essence of the requirements for the implementation of research functions by a teacher during the formation of soft skills is as follows:

- identification of contradictions, connections and patterns of the formation of "soft skills" in students of humanitarian and natural specialties;

- defining the principles and approaches on the basis of which his activities will be built in the process of forming these skills (personal, activity, systemic, axiological, praxeological, competence, etc.);

- clarifying the conditions that affect the process of formation and development of soft skills in students;

- analysis of scientific sources on the structure of soft skills, mechanisms and means of their development in various segments of education;

- in-depth study of relevant information in order to provide pedagogical guidance in the process of forming students' soft skills and building a strategy to master them;

- systemic actions of the teacher in the process of organizing students' independent work to improve their own skills;

- the choice of one or another mechanism of educational influence (direct / indirect) on students in the formation of their soft skills in various situations of interaction;

- determining the level of students' readiness to form these skills with the help of a specific pedagogical tool;

- classification of obtained facts in order to provide practical recommendations to other teachers regarding the process of forming soft skills in students.

\section{The design function}

The design function of a teacher is multifaceted like the entire activity of a teacher in higher education. According to N. Volkova (Volkova, 2017: 190), the design process can be viewed as a combination of the following technological units: the choice of strategy, content, form, methods of interaction with students, as well as the definition of means that ensure the joint activities of participants in the educational process; pedagogical communication as a means of building a certain strategy of behavior with students; analysis of targeted results and actual outcomes.

Summarizing views of researchers (Demchenko, 2017; Volkova, 2017; Mednikova, 2017; Omarova, Alizhanova, Omarov, 2016) depending on the content of this function, we came to the conclusion that the project requirements related to the formation of soft skills includes forecasting the development of soft skills based on a thorough analysis of sources for the specified problem and determining the resource base of the educational process in a particular institution of higher education; teachers and students modeling various types of activities for mastering soft skills aimed at gaining experience in the field of communication, team building, teaching and training others, displaying emotions and evaluative actions; planning how to manage these activities; creation of a specific model for the formation of these skills in accordance with the stages of the teacher's design activities; the choice of ways to bring this model into practice; and the assessment of its effectiveness.

We identified stages of the teacher's design activities based on the analysis of the work of M. Demchenko (Demchenko, 2017: 210). Their adaptation for the process of forming soft skills in students allows us to state that while forming soft skills we deal: 1) at the stage of conceptual design with the development of an ideal model of the development of these skills which includes certain components in the form of subsystems; 2) at the stage of functional projecting with planning the framework of the model; finding its functional possibilities and possibilities of interconnecting its constituent subsystems; 3 ) at the final stage of structural projecting with the fine tuning necessary to put the ideal model into reality. 


\section{Organizational and managerial function}

The essence of the organizational and managerial activity of the teacher can be determined through the way respective functions are executed.

Scientists (Rudevich, 2016: 89-90) determine the content component of the managerial function through the acts of planning activities, its organization, motivation of participants, control and coordination of actions.

Some researchers (Aleksandrova, 2012; Polovenko, 2015) assess basic knowledge of teachers through their managerial actions related to the activities of students, their value orientations, and the ability to give a timely adequate response to students' requests.

Usually, teachers basic knowledge of student management result from processing, analyzing and structuring information from various sources. They are shaped by internal and external factors and should be used when the teacher makes the right decisions aimed at achieving the goals (Zhuk, 2011: 26) in the process of interaction with students taking into account ethical and psychological and pedagogical norms.

In addition to knowledge that makes the theoretical basis of teacher's activity in order to carry out the organizational and managerial function the teacher also needs developed skills, which are a reflection of his ability to work in a practical plane. These include (Cherednichenko, Shapran, Kunytsia, 2011; Frolova, 2006; Rudevich, 2016; Sladkevych, Cherniavskyi, 2007) creation of a positive emotional climate which makes students psychologically relaxed and increases his motivation to carry out a specific type of activity; regulating relations between participants in the process of achieving the goals; planning, allocation and reallocation of resources during the realization of goals; diagnosing the process of obtaining certain skills by students, controlling the implementation of assigned tasks.

The analysis of the content of the organizational and managerial functions allowed us to formulate the requirements to teachers' activity in the formation of soft skills in students of humanitarian and natural specialties:

those related to the planning process:

* implementation of planning acts on the basis of available experience (own and students') in the formation of soft skills in classroom and during extracurricular activities, taking into account "gaps" and miscalculations in activities;

* determining the purpose of interaction and setting out its details at certain stages of the process by providing students with guidance and specifying the timing an of their implementation;

* setting out in detail the ways to resolve issues through the use of particular pedagogical techniques, methods, and approaches (for example, in order to develop critical thinking of students as a component of soft skills we recommend to use such methods as "brainstorming", "Delphi", chamomile Bloom, Vienna charts, work in pairs, etc.);

* paying attention to resources necessary to create soft skills (technical and informational ones, as well as determining mandatory and additional content, especially in the context of joint learning);

* outlining a clear plan of action, determining the content of each component

* prediction of possible results and consequences of activities; those related to motivation:

* clarification of motives of students' behavior and the degree of relevance of their skills (self-organization, communication, teamwork, leadership, career, etc.);

* determination of ways and means of stimulating activity of students (for example, through the organization by students of disputes, trainings, round tables, where they play the role of organizers, moderators, trainers);

those related to execution of control:

* focus on forms and means of control, filling them with relevant content (for example, 
possible forms of control can be seminars conducted by students on a specified topic, publication of summaries or articles in scientific publications with or without the teacher's participation, project work, concert performances, organization of flash mobs and workshops, where students show and improve their soft skills);

those related to coordination of actions:

* ensuring effective interaction by means of coordination of actions and synchronization of work between the participants; defining methods and content of coordination work; redistribution of responsibilities, if necessary; implementation of corrective actions concerning changes in the plan of activities, or in the actions of the participants when they perform a specific task

\section{Predictive function}

The formation of person's ability to predict through as part of self-regulation is viewed by modern researchers as vital in the process of teaching students in educational institutions (Zeer, Stepanova, 2017).

A teacher should also have these abilities, for which reason scientists (Davkush, 2011: 235-236) focus on the directions of forecasting as a teacher's function in socio-pedagogical, methodological, experimental and personality-oriented dimensions and point to the emergence of special terminology. This set of terms was made up of the following phrases: "expectation of success", "expectation of academic performance", "anticipation of test scores", "anticipation of changes in self-esteem".

One of the conditions for forecasting is anticipation (Tolstosheina, 2002) as the ability to foresee and reflect ahead of time future events at the psychophysiological level.

Components of pedagogical forecasting are (Polak, 1971: 248-251) as follows: intuition on the background of a high level of personal development; fantasy as a product of human imagination; creativity, with the help of which the assigned tasks are resolved in an extraordinary way.

Forms of pedagogical forecasting include planning, goal-setting, projecting and programming. A feature of such a form as planning is logical thinking and practical experience of the individual (Encel, Marstrand, Page, 1975), the presence of which makes the forecasting process more substantiated. Goal-setting is viewed an integral part of forecasting; it is the basis for a wide range of human activities in the process of transforming a requirement into a specific action. Projecting and programming are viewed as forms that add the detail to goals and objectives (Willis, 1987).

Among the levels of predictive abilities of a person, the emphasis is made on personal and cognitive factors (Regush, 1997).

Analysis of the views of scientists (Davkush, 2011; Encel, Marstrand, Page, 1975; Regush, 1997; Tolstosheina, 2002; Willis, 1987) on this issue allows us to state that predictive requirements in the formation of soft skills include

- the teacher's definition of main directions of his activity by forming these skills in students based on the conditions, forms, components, and levels of forecasting;

- foreseeing the results of activity in accordance with the goals set, both in general and at each stage of work;

- expectation of several options for resolving the task taking into account the details of a particular situation;

- forecasting the results and consequences of their own professional actions. 


\section{Methodological function}

The level of formation of soft skills among students is significantly influenced by the execution of the methodological function by the teacher.

Methodological work as an integral part of the teacher's scientific and pedagogical activity includes setting specific tasks Berdennikova, Medencev, Panov, 2006: 5; Kondrashova, Permiakov, Zelenkova, Lavreshyna, 2006: 234; Rapacevich, 2005: 307); meaningful saturation (Kondrashova, Permiakov, Zelenkova, Lavreshyna, 2006: 238); system of principles as the basis of its organization (Berdennikova, 2007; Kondrashova, Permiakov, Zelenkova, Lavreshyna, 2006: 237; Tamozhnyaya, 2010); and certain functions (Eroshina, 2000; Kondrashova, Permiakov, Zelenkova, Lavreshyna, 2006: 238). Links between these elements are based on the acts of interaction between the teacher and students and the assessment of the results of their activities.

In terms of formation of Soft Skills in students, we emphasize the following components of content of the methodological work of a higher school teacher, namely:

- study of the work plans of the academic disciplines in order to obtain data on the possibilities of forming "soft skills";

- developing a plan on this basis of extracurricular activities which will expand the boundaries of interaction between the teacher and students;

- developing a scientific and methodological complex whose materials will help students to go through the full cycle of the formation of these skills from setting a goal to reflecting on their own activities;

- mastering the principles and methodological techniques of organizing and conducting trainings, round tables, workshops, speaking clubs and other forms of organizing educational activities that contribute to the formation and development of students' soft skills in classroom and during extracurricular work;

- creating a bank of interesting methodological techniques and advice the use of which will provide significant assistance to both teachers and students in the process of developing and improving these skills;

- studying the experience of well-known specialists who are active users of modern soft skills techniques: effective communication, critical and creative thinking, emotional intelligence, leadership, team building, self-organization, etc.

- organization and conduct of activities by teachers (on their own / with the help of students) with the help of active learning methods which will allow students to play various roles that they will have to face in future professional activity to gain experience in building a career strategy;

- methodological support of students in the process of forming soft skills during various types of practice (introductory in secondary schools and as assistants in high schools).

\section{Facilitative function}

Modern researchers view the pedagogical facilitative function as:

1) a process focused on improving the efficiency and productivity of education as part of cooperation between students and the teacher on the basis of subject-to-subject relation (Chabanenko, 2020: 656; Fil, 2013; Fil, 2017; Muhametzyanova, Hajrutdinov, 2017: 45);

2) the method of interactive teaching in higher education aimed at stimulating the processes of self-education and self-development of students (Plotnikova, Nizhelskoj, 2019; Rajs, 2014). These processes become more effective if a psychologically favorable climate is created during the interaction of the teacher and the students.

Facilitation is usually carried out in group work (Sokolova, 2013: 131).

Some researchers propose to consider the definition of "facilitation" as a component of pedagogical management in various types of educational activities of students (Muhametzyanova, 
Hajrutdinov, 2017: 48). Management acts are carried out by means of the teacher acting as a "neutral leader" or an "orchestra conductor" (Sokolova, 2013: 131). In the process of fulfilling these roles the teacher encourages participants to concentrate on joint goals and content of work that needs to be done; offers students possible ways of resolving the problem, supports the activity of group members in expressing their judgments during discussions without imposing their vision and supporting the position of all parties; guides students' actions towards obtaining the desired result.

In general, the goal of facilitation in higher education is to develop the subjectivity of students through disclosure of their personality at all stages of the educational process by means of pedagogical support (Borytko, 2005: 68).

Some scientists present the algorithm of teacher's actions as part of pedagogical support as an "attributive circle" of the facilitation process (Muhametzyanova, Hajrutdinov, 2017: 48). It includes a certain order as the teacher performs acts to provide support to students in the following areas: motivational; target; search (concerns the subject, methods and means of knowledge); activity; and the reflective.

Based on the analysis of the above-mentioned sources, we define the following main features of facilitative actions of the teacher in the formation of students' soft skills:

- organization of multilevel interaction in the "teacher-to-student" and "student-to-student" mode in accordance with the "attributive circle" of the facilitation process;

- partnership style of interaction between the teacher and students;

- emphasis on the processes of self-improvement and self-development of personal and professional qualities by students in conditions of pedagogical support;

- functional and organizational unification of the actions of teachers and students through a clear action plan and observing its main provisions on the basis of diagnosing the problem that has arisen; availability of information on how to resolve it; consultations with the teacher in the process of making a unified decision; providing timely assistance, if necessary, in the implementation of goals;

- the use of facilitation methods in the process of conducting seminars with students, organizing conferences, analyzing problem situations, working on projects, generating new ideas by them during group communication;

- the manifestation (if necessary) of the teacher's personal attitude to the acts of interaction in order to determine attitudes and motives of students, prevent conflict situations, correct actions and find ways to overcome difficulties.

\section{Conclusions}

All of the above allows us to make the following conclusions:

1. All functions performed by the teacher in daily activities are interrelated and interdependent.

2. Knowledge of the content of each of these functions (educational, didactic, research, design, organizational and managerial, prognostic, methodological, facilitative) determines the specifics of requirements to a higher school teacher in the process of forming students' soft skills.

3 . The general requirements to a teacher's actions, regardless of the specifics of a particular function, are his readiness to overcome obstacles that stand in the way of forming students' soft skills in typical and atypical situations; ability to adjust and flexibility in solving assigned tasks; balanced reaction when responding to the situation; partnership and a high level of interaction; the ability to provide timely assistance to students and support them in the process of forming their own image, correcting personal and professional growth; analysis of the results of their activities and the consequences to which these actions led.

We see prospects for further research in a detailed study of the pedagogical conditions that contribute to the development of soft skills in students in various educational segments. 


\section{References}

Aleksandrova, N. (2012) Vzaiemozviazok upravlinskoi kompetentnosti ta upravlinskoi kultury vykladacha [The interconnection between the managerial competence and the managerial culture of the teacher]. Problemy pidhotovky suchasnoho vchytelia, no 5 (ch. 1), pp. 138-143. [in Ukrainian]

Berdennikova, N. G. (2007) Metodicheskoe obespechenie processa obucheniya kak faktor povysheniya kachestva obrazovaniya $v$ vuze [Methodological support of the educational process as a factor to improve quality of education at the university] (PhD Thesis), SanktPeterburg. [in Russian]

Berdennikova, N. G., Medencev, V. I., Panov, N. I. (2006). Organizacionnoe i metodicheskoe obespechenie uchebnogo processa $v$ vuze [Organizational and methodological support of the educational process at the university]. Sankt-Peterburg: D.A.R.K. [in Russian]

Bibik, N. M. (ed.) (2017). Nova ukrainska shkola: poradnyk dlia vchytelia [New Ukrainian School: A Teacher's Guide]. Kyiv: TOV Pleiady. [in Ukrainian]

Bobro, A. A. (2017) Formuvannia sotsialnoho zdorovia studentskoi molodi u pozaaudytornii vykhovnii roboti vyshchoho navchalnoho zakladu [Forming social health of students in the extracurricular work of the university] (PhD Thesis), Kyiv: Skhidnoukr. nats. un-t im. Volodymyra Dalia. [in Ukrainian]

Bordovskaya, N., Rean, A. (2011). Pedagogika: ucheb. posobie [Pedagogy: schoolbook]. Sankt-Peterburg: Piter. [in Russian]

Borytko, N. M. (2005). Sistema professionalnogo vospitaniya $v$ vuze [The system of professional education at the university]. Moskva: APK i PPRO. [in Russian]

Breslavska, H. B. (2013). Formuvannia kultury dozvillia studentiv vyshchykh pedahohichnykh navchalnykh zakladiv zasobamy proektiv u pozaaudytornii roboti [Forming the leisure culture of higher education students through extracurricular projects] (PhD Thesis), Uman: Uman. derzh. ped. un-t im. Pavla Tychyny. [in Ukrainian]

Chabanenko, S. V. (2020). Pedagogicheskaya fasilitaciya v usloviyah distancionnogo obrazovaniya [Pedagogical facilitation as part of distance learning]. Molodoj uchenyj, no 20 (310), pp. 656-657. [in Russian]

Cherednichenko, H. A., Shapran, L. Yu., Kunytsia, L. I. (2011). Formuvannia upravlinskoi kompetentnosti maibutnikh menedzheriv u protsesi fakhovoi pidhotovky u VNZ III-IV rivniv akredytatsii [Forming managerial competence of future managers during professional training at universities of III-IV degree of accreditation]. Naukovyi visnyk Natsionalnoho universytetu bioresursiv i pryrodokorystuvannia Ukrainy. Seriia «Pedahohika. Psykholohiia. Filosofiia», vol. 159 (ch. 1), pp. 329-337. [in Ukrainian]

Davkush, N. (2011). Pedahohichne prohnozuvannia u systemi profesiinoi osvity: istorychnyi aspekt [Pedagogical forecasting in the professional education system: the historical aspect]. Problemy pidhotovky suchasnoho vchytelia, no 4 (ch. 2), pp. 232-238. [in Ukrainian]

Demchenko, M. O. (2017). Didakticheskoe proektirovanie v professionalnoj deyatelnosti pedagoga [Didactic projecting in teachers' professional activity]. MNKO, no 6 (67), pp. 208-211. [in Russian]

Dubaseniuk, O. A. (2005). Teoriia i praktyka profesiinoi vykhovnoi diialnosti pedahoha [Theory and practice of teachers' professional activities]. Zhytomyr: ZhDU im. Ivana Franka. [in Ukrainian]

Dubaseniuk, O. A. (2013). Struktura doslidnytskykh pedahohichnykh umin ta umovy yikh rozvytku [The structure of teachers' research skills and conditions for their development]. 
Proceedings of the Doslidnytskyi komponent u diialnosti zahalnoosvitnikh navchalnykh zakladiv ta pozashkilnykh zakladiv osvity: retrospektyva i perspektyva (Ukraine, Kyiv, November21, 2013). Kyiv.: Instytut obdarovanoi dytyny, pp. 20-31. [in Ukrainian]

Encel, S., Marstrand, Pauline K., Page, W. (ed) (1975). The art of anticipation: values and methods in forecasting. New York: Pica Press.

Eroshina, V. I. (2000). Pedagogicheskie usloviya sovershenstvovaniya metodicheskoj raboty po realizacii obshego i professionalnogo obrazovaniya [Pedagogical conditions for improving methodological work in general and professional education] (PhD Thesis), Moskva. [in Russian] Fil, T. A. (2013) Soderzhatelnye harakteristiki gotovnosti k fasilitacii pedagoga [Characteristics of teacher's readiness for the facilitation process]. MNKO, no 5 (42), pp. 24-27. [in Russian] Fil, T. A. (2017). Fasilitaciya $v$ sisteme vysshego obrazovaniya [Facilitation in the higher education system]. Mezhdunarodnyj nauchnoissledovatelskij zhurnal, no 7(61), pp. 102-104. [in Russian]

Frolova, N. V. (2006). Organizacionno-pedagogicheskie usloviya formirovaniya professionalnyh kompetencij u studentov upravlencheskih specialnostej [Organizational and pedagogical conditions for the formation of professional competencies of students of management specialties]. Yaroslavskij pedagogicheskij vestnik, no 3, pp. 61-65. [in Russian]

Halatsyn, K. O. (2014). Formuvannia komunikatyvnoi kultury studentiv vyshchykh tekhnichnykh navchalnykh zakladiv u protsesi pozaaudytornoi roboty [Forming the communicative culture of technical school students educational institutions during extracurricular work] (PhD Thesis), Uman: Uman. derzh. ped. un-t im. Pavla Tychyny. [in Ukrainian]

Honcharenko, S. U. (2012). Pedahohichni zakony, zakonomirnosti, pryntsypy. Suchasne tlumachennia [Pedagogical laws, patterns and principles. Modern interpretation]. Rivne: Volynski oberehy. [in Ukrainian]

Human Development Report 2019 (2019). United Nations Development Programme, New York. Humennykova, T. R. (2004). Potentsiini mozhlyvosti pozaaudytornoi roboty shchodo pidhotovky studentiv do osobystisno oriientovanoho vykhovannia [Potential opportunities of extracurricular work in preparing students for personality-driven education]. Naukovyi visnyk Pivdennoukrainskoho derzh. ped. un-tu, vol. 12, pp. 58-61. [in Ukrainian]

Ibragimov, G. I., Ibragimova, E. M., Andrianova, T. M. (2011). Teoriya obucheniya [Theory of education]. Moskva: VLADOS. [in Russian]

Kondrashova, L. V., Permiakov, O. A., Zelenkova, N. I., Lavreshyna, H. Yu. (2006). Pedahohika v zapytanniakh i vidpovidiakh [Pedagogics in questions and answers]. Kyiv: Znannia. [in Ukrainian] Koval, V. Yu. (2009). Systema pozaaudytornoi diialnosti studentiv vyshchykh navchalnykh zakladiv [The system of extracurricular activities of higher education students]. Naukovi pratsi Donetskoho natsionalnoho tekhnichnoho universytetu. Seriia «Pedahohika, psykholohiia, sotsiolohiia», no 6, pp. 19-23. [in Ukrainian]

Mednikova, L. A. (2017). Pedagogicheskoe proektirovanie deyatelnosti, kak effektivnaya obrazovatelnaya tehnologiya [Pedagogical projecting of activities as an effective educational tool]. Vestnik Kostromskogo gosudarstvennogo universiteta. Seriya: Pedagogika. Psihologiya. Sociokinetika, no 2, pp. 12-14. [in Russian]

Muhametzyanova, F. G., Hajrutdinov, R. R. (2017). O fenomene fasilitacii v vysshem obrazovanii [The phenomenon of facilitation in higher education]. KPZh, no 1(120), pp. 45-50. [in Russian] Omarova, M. O., Alizhanova, H. A., Omarov, O. M. (2016). Formirovanie i razvitie umenij pedagogicheskogo proektirovaniya $v$ sisteme professionalnoj podgotovki sovremennogo uchitelya [Forming and developing pedagogical projecting skills in the system of professional training of modern teachers]. Obrazovanie lichnosti, no 3, pp. 29 - 38. [in Russian] 
Ovcharenko, H. E. (2008). Pozanavchalna diialnist studentiv u vyshchykh navchalnykh zakladakh: sutnisni kharakterystyky, struktura ta osoblyvosti [Extracurricular activity of students in higher educational institutions: essential features and structure]. Osvita Donbasu, no 5-6 (130-131), pp. 35-38. [in Ukrainian]

Pachauri, D., Yadav, A. (2014). Importance of Soft Skills in Teacher Education Programme. IJERT, vol. 5 (1), pp. 22-25.

Petrychenko, L. (2010). Systema pozaaudytornoi roboty, spriamovanoi na pidhotovku maibutnoho vchytelia do tvorchoi profesiinoi diialnosti [The system of extracurricular work aimed at preparing future teachers for creative professional activities]. Humanizatsiia navchalnovykhovnoho protsesu, vol. 11, pp. 33-40. [in Ukrainian]

Plotnikova, I. E., Nizhelskoj, D. A. (2019). Ispolzovanie metoda fasilitacii v professionalnoj podgotovke ordinatorov [The use of facilitation in the professional training of university residents]. Mir nauki. Pedagogika i psihologiya, no 2. Retrieved from: https://mir-nauki.com/ PDF/82PDMN219.pdf (accessed 23.07.20).

Polak, F. L. (1971). Prognostics: a Science in the making surveys and creates the future. Amsterdam, New York: Elsevier Pub. Co.

Polovenko, L. (2015) Upravlinska kompetentnist - kliuchovyi skladnyk profesiinoi kompetentnosti maibutnikh fakhivtsiv ekonomichnoho profiliu [Managerial competence as a key component of professional competence of future economists]. Hirska shkola ukrainskykh Karpat, no 12-13, pp. 220-223. [in Ukrainian]

Rajs, O. I. (2014). Fasilitaciya, kak metod interaktivnogo obucheniya [Facilitation as an interactive learning tool]. Psihologiya, sociologiya i pedagogika, no 7. Retrieved from: http:// psychology.snauka.ru /2014/07/3317 (accessed 23.07.20).

Rapacevich, E. S. (2005). Pedagogika. Bolshaya sovremennaya enciklopediya [Pedagogics. Big modern encyclopedia]. Minsk: Sovrem. slovo. [in Russian]

Regush, L. A. (1997). Psihologiya prognozirovaniya: sposobnost, ee razvitie i diagnostika [The psychology of forecasting: ability, its development and diagnosis]. Kiev: Visha shkola. [in Russian]

Rudevich, N. (2016). Formirovanie organizacionno-upravlencheskoj kompetentnosti budushih inzhenerov po avtomatizacii energosistem [Forming organizational and managerial competence of future engineers of power systems automation]. Teoriia i praktyka upravlinnia sotsialnymy systemamy, no 2, pp. 87-98. [in Russian]

Shvab, K. (2017). Chetvertaya promyshlennaya revolyuciya: perevod s anglijskogo [fourth industrial revolution: translation from English]. Moskva: «E». Retrieved from: http://ncrao. rsvpu.ru/sites/default/files/library/k._shvab_chetvertaya_promyshlennaya_revolyuciya_2016. pdf (accessed 16.04.20).

Skill Shift Automation And The Future Of The Workforce (2018). Retrieved from: https://www. mckinsey.com/featured-insights/future-of-work/skill-shift-automation-and-the-future-of-theworkforce (accessed 16.04.20).

Skrypnyk, N. S. (2012). Pozaaudytorna diialnist studentiv vyshchykh navchalnykh zakladiv: sutnist, struktura y osoblyvosti [Extracurricular activity of higher education students: essence, structure and features]. Pedahohika formuvannia tvorchoi osobystosti u vyshchii i zahalnoosvitnii shkolakh, vol. 27 (80), pp. 566-571. [in Ukrainian]

Sladkevych, V. P., Cherniavskyi, A. D. (2007). Suchasnyi menedzhment orhanizatsii [Modern management of organizations]. Kyiv: MAUP. [in Ukrainian]

Slastenin, V. A., Isaev, I. F., Mishenko, A. I., Shiyanov, E. N. (2000). Pedagogika [Pedagogics]. Moskva: Shkola-Press. [in Russian] 
Snape, P. (2017). Enduring Learning: Integrating C21st Soft Skills through Technology Education. Design and Technology Education, vol. 22. no 3. Retrieved from: https://ojs.lboro. ac.uk/DATE/article/view/2222/2585 (accessed 19.07.20).

Sokolova, E. I. (2013). Analiz terminologicheskogo ryada «Kouch», «Mentor», «Tyutor», "Fasilitator», "Edvajzer»v kontekste nepreryvnogo obrazovaniya [Analyzing terms "Coach", "Mentor", "Tutor", "Facilitator", "Advisor" in the context of nonstop education]. Nepreryvnoe obrazovanie: XXI vek, no 4, pp. 124-135. [in Russian]

Tamozhnyaya, E. A. (2010). Sistema metodicheskoj podgotovki uchitelya geografi $v$ pedagogicheskom vuze $v$ usloviyah modernizacii obrazovaniya [The system of methodological training of geography teachers at a pedagogical university in the context of education modernization] (PhD Thesis), Moskva. [in Russian]

Tolstosheina, N. V. (2002). Anticipaciya kak odno iz uslovij prognozirovaniya, vybora i regulyacii budushej deyatelnosti [Anticipation as one of the conditions for forecasting, choosing and regulating future activity]. Gaudeamus, no 2, pp. 41-46. [in Russian]

Volkova, N. V. (2017). Tehnologiya proektirovaniya obrazovatelnyh sobytij. [Ways of projecting educational events] Obrazovanie i nauka, no 4, pp. 184-200. [in Russian]

Willis, R. E. A guide to forecasting for planners and managers. Englewood Cliffs, NJ: Prentice Hall, 1987.

Zagvyazinskij, V.I., Atahanov, R. A. (2010). Metodologiya i metody psihologo-pedagogicheskogo issledovaniya [Methodology and methods of psychological and pedagogical research]. Moskva: Akademiya. [in Russian]

Zeer, E. F., Stepanova, L. N. (2017). Psihologicheskie osobennosti vzaimosvyazi prognosticheskih sposobnostej i samoregulyacii povedeniya studentov [Psychological features of Interconnection between predictive abilities and self-regulation of students' behavior]. Pedagogicheskoe obrazovanie v Rossii, no 2, pp. 46-52. [in Russian]

Zhuk, N. A., Zhuk, L. V. (2011). Obshaya metodologiya effektivnogo upravleniya $i$ samoupravleniya. ( $V$ kratkom izlozhenii) [General methodology of effective management and self-government. (brief)]. Harkov: OOO «Infobank». [in Russian] 